\title{
The intersectionality of religion, race and gender at the time of COVID-19 pandemic: A South African reflection
}

\author{
Dr. Itumeleng D. Mothoagae \\ Institute for Gender Studies,College of Human Sciences,University of South Africa \\ ORCID https://orcid.org/0000-0002-9644-0371 \\ E-mail:mothodi@unisa.ac.za \\ Prof. Azwihangwisi Mavhandu-Mudzusi \\ Graduate Studies and Research, College of Human Sciences, \\ University of South Africa \\ ORCiD https://orcid.org/0000-0002-6916-8472 \\ mmudza@unisa.ac.za
}

Doi: https://doi.org/10.46222/pharosjot.102.220

\begin{abstract}
This paper presents the intersectionality of religion, race, and gender during the COVID-19 pandemic from a South African perspective. Though COVID-19 has affected every area in South Africa, the intersectionality of religion, race, gender class has begun to be interrogated by scholars, NGOs, and faith-based organizations. The interpretative phenomenological analysis study was conducted at a South African rural-based hospital, which is comprised of black personnel who serve only black people from impoverished villages. The data were collected from 11 nurses who had suffered from COVID-19. Following Pietkiewicz and Smith's (2014:7) steps of thematic data analysis, results indicated that nurses who suffered from COVID-19 had faced the dilemma of administering Western medicine or traditional African medicine. In other words, the universality of western medicine as effective and scientific created an epistemological dilemma for those that viewed traditional African medicine as an alternative to western medicine. As such, this was also necessitated by the view that Western medicinal treatments were not as effective in comparison to traditional African medicine. This view indicates the effectiveness of perception. Succinctly put, the social and epistemic location of the participants functioned as an epistemological discourse in engaging the notion of the 'supremacy' of Western medicine and the choice of administering both Western and traditional medicinal treatments. The choice of opting to administer both medicinal treatments was also necessitated by the scarce resources and access to hospital facilities. At the same time, the notion that traditional administration of medicines to treat COVID-19 was also viewed as an act of heathenism, based on religious belief. The intersectionality of religion and class became evident as illustrated in the findings that surrendering one's life to God through prayer was important and central for those infected and affected by COVID-19 instead of administering traditional African medicines. While there appears to be no objection to administering Western medicines, suggesting the convergence of both epistemologies as superior to the traditional epistemologies. Applying a decolonial analysis, the paper seeks to argue that there is a need to decolonise religion (western Christianity) in order to deconstruct the notion of traditional epistemologies as heathenism. This is in order to the delink so as to advance the notion of pluriversality and broader-thinking.
\end{abstract}

Keywords: colonial matrix of power, religion, gender, race, spiritual epistemicide, colonial matrix of power, coloniality of power, coloniality of being.

\section{Introduction}

As a social construct, religion has played a role in sustaining society. As an institutional structure within society, religion, like social structures such as family, schools, and state, has 
functioned as a space of socialising its members through social identities and internalizing its values through structures such as churches, temples, mosques, norms, statues. Foucault has righltly argued that:

The fundamental codes of culture - those governing its language, its schemas of perception, its exchanges, its techniques, its values, the hierarchy of its practices - establish for every man, from the very first, the empirical orders with which he will be dealing and within which he will be at home (1989:xxii).

The argument by Foucault illustrates how the various strata of society function as a space for socialisation, a technology of power and surveillance aimed at universalising its fundamental codes of culture, namely attitudes, values, and action deemed appropriate for those that are its members by virtue of belonging to a particular culture or system. Following the argument by Foucault, Christianity, like many other religions, functions in a similar manner. For that reason, it has functioned as an imperial tool to colonise, convert, and civilise. Throughout history, Christianity has been viewed as both negative and positive in terms of its role in society. COVID-19, like many other pandemics throughout history, has brought uncertainties, faith crisis, and various interpretations of what these phenomena might entail, such as an apocalyptic reading of the pandemics and reading the Biblical texts into the pandemics such as COVID-19. South Africa was not spared from these views of apocalyptic interpretation. The essay presents the intersectionality of religion, gender, and race at the time of COVID-19. The paper argues that to map the impact of religion (Christianity) in the context of South Africa, the point of departure has to be that of locating the geo and theo politics of knowledge as technologies of power and surveillance that religion (Christianity) has performed. This view is observed in terms of the social location and the epistemic location of those affected and infected by the virus (COVID-19). The essay further locates the role of digitisation as a form of religious communication in the era COVID-19 pandemic.

Applying Pietkiewicz and Smith's (2014:8) steps of thematic data analysis, results indicated that nurses who suffered from COVID-19 had faced various dilemmas regarding administering Western medicine or traditional African medicine. It is argued that such a dilemma is the effects and impact of Western Christianity as it was used as a technology to erode the indigenous knowledge systems as well as constructing an epistemic privilege of western knowledge systems. Thus, leading to epistemic violence and spiritual epistemicide. At the same time, it may be argued that such a strategy of using Western epistemology as a rubric and regimes of truth through religiosity and socialisation did not succeed as Africans continue to believe that Western medicines are not in themselves that effective. Even though, as an epistemological rubric, the supremacy of western codes of culture in terms expressed in the choice of a health system has not prevented some of those infected by the virus from not seeking other alternative forms of treatment.

\section{Religion as a technology of power and surveillance: Negative impact of religion on the management of pandemics}

As an imperial and colonial vehicle to convert, civilise and colonise Black bodies in South Africa, the missionary enterprise used the Bible as an imperial 'tool'. To achieve these, they depicted and projected the Bible as a book of hope and healing. This view is held by West $(2016: 1)$ in his book where he states that:

My story tells how the Bible was brought to Southern Africa as part of a project of imperialism and trade, of conversion and civilisation, of colonialisation and conquest; the story of missionaries and the colonial agents transacted with this Bible among African peoples, the story of how the Bible was translated from European languages to African languages; the story of how Africans 
appropriated the Bible, wresting it from the hands of those who brought it; the story of how the Bible became a contested book West (2016:2).

The above citation depicts the mechanisms employed by both the missionaries and colonial agents to erode and colonialise the black body using the Bible. Such a context is imperative to locate the role of the Christian religion in the context of the COVID-19 pandemic. Christianity as bearing the marks of colonialism, oppression, segregation, marginalisation and erosion, has functioned as a powerful tool not only to perform spiritual epistemicide by locating indigenous religions, spiritualities, and knowledge systems as heathenistic in character and by introducing western colonial thought to perform a technology of erasure (Mothoagae, 2018:4). The impact of these effects on spiritual and epistemological awareness has produced dire consequences. This view has been argued by Steve Biko (1978:31) that the message of the Bible must be defined, and made relevant to the struggling masses, particularly in the context of despair. This, according to him, will address the spiritual deprivation and the gullibility of Black people in the way they read and analyse the biblical text. However, the argument advanced by Biko was written prior to the COVID-19 pandemic. Therefore, his analysis is imperative for us to engage with the impact of religion in general, particularly Christianity, on COVID-19. The pandemic brought to the fore and laid bare the role of religions and the idea of a pluriversality of religions versus the universalisation and supremacy of one religion over the others. Furthermore, decoloniality as a theoretical lens has necessitated the conversation around the dichotomisation of religion, namely to oppress and liberate.

The Bible, as a spiritual book read from the existential experience of gender disparity, poverty, race, and economic marginalisation within the unrelenting conditions exacerbated by COVID19 , has functioned as a book of hope. Put succinctly, read from the location and experience of the damnés, the Bible serves as a liberating tool and attempts to do away with spiritual poverty (spiritual epistemicide), resulting from the colonialist missionary agenda.

A complete lockdown at the beginning to try and curb the spread of the virus exposed the religious dependency and the tensions between religion and science. These two dimensions raised epistemological debates and provided a conceptual space for both systems to be put under surveillance. As a book of faith, the Bible has been at the centre of these epistemological debates, particularly the Book of Revelation. This is evidenced in the use of biblical texts to seek to locate the COVID-19 vaccines as bearing the marks of the anti-Christ. While at the time, the belief in the miraculous acts of the divine seems to have been the core argument on the labelling of such scientific interventions as acts of Satan. Steve Biko (1978:28) reminds us that,

The fact that apartheid has been tied up with white supremacy, capitalist exploitation, and deliberate oppression makes the problem much more complex. Material want is bad enough but coupled with spiritual poverty kills.

The observation by Biko on the notion of spiritual poverty is demonstrated in the statement made by the South African Chief Justice, Mogoeng Mogoeng. Grobler (2020) reported, the Chief-Justice Mogoeng Mogoeng, in a statement made when he led a prayer meeting at Thembisa hospital, said the following:

If there be any vaccine that is of the devil, meant to infuse triple-six in the lives of people, meant to corrupt their DNA, any such vaccine, Lord God Almighty, may it be destroyed by fire, in the name of Jesus.

The statement by Mogoeng Mogoeng needs to be contextualised within the legacy of Christianity in South Africa and the various religious approaches onhow the texts are appropriated and interpreted. In other words, the lens through which the text is read is fundamental in locating his argument. Simultaneously, his interpretation and fundamentalist 
appropriation of the biblical text also points to the power of the written word expressed in the form of regimes of truths, a criterion, and a yardstick of what is acceptable and not acceptable. This was also evident at the time when HIV and AIDS were wreaking havoc in communities. The Christian churches were at the forefront of denying the use of condoms, basing their argument again on the Bible and Christian dogmas. Such an observation is encapsulated in the argument by Marshall in relation to the inordinate amount of time and energy the church has devoted. He (Marshall) states, "pelvic issues- sexuality, reproduction, and abortion-which receive nothing like the same degree of attention in scripture" (2005: 18).

At the same time, religion is a social construct and a mechanism to make sense of human experiences and their phenomenon. In South Africa, Western colonial Christianity has functioned as a source of hope and as a rubric and surveillance based on the notion of a regimes truth in Foucauldian terms. Succinctly put, in South Africa, the Christian religion has performed surveillance of the Black body through a technology of disciplinary power. Foucault (1975) employs the notion of disciplinary power to delineate the various modes of power or biopower. He views power (biopower) as a major source of societal discipline and conformism. He argues that biopower or disciplinary power is the move from supreme to life-giving power observed in the organisational systems and communal services created in $18^{\text {th }}$ century Europe. For example, prisons, schools, and mental institutions include religious movements and institutions and how they no longer required violence through their surveillance and assessment systems. Foucault states,

\begin{abstract}
This form of power is salvation-oriented (as opposed to political power). It is oblative (as opposed to the principle of sovereignty); it is individualizing (as opposed to legal power); it is coextensive and continuous with life; it is linked with the production of truth- the truth of the individual himself. In a way, we can see the state as a modern matrix of individualization or a new form of pastoral power (Foucault, 1983:783).
\end{abstract}

Based on the citation above, it can be argued that religion as a form of biopower has not only performed surveillance over bodies, throughout history in moments of despair, crisis, catastrophes have functioned as a source of hope. Smith, Pargament, Brant and Oliver (2000:169) have argued that although people use religion to solve various problems, religion is primarily used to cope with negative and unpredictable situations (Ede \& ZoukeKalu, 2021:3). At the same time, it has also functioned as a discursive tool, an epistemological norm to subvert other truths. In other words, based on the notion of the normativity of the regimes truths of the western religio-cultural practice, reliance on a higher Being in moments of doubt rather than on indigenous spiritualities. Thus, functioning as a technology of a so-called emotion-focused coping mechanism aimed at reducing the psychological distress that people experience in such situations (Ede \& ZoukeKalu, 2021:4). In the following section, we will briefly discuss the positive elements of religion at the time of COVID-19.

It is no doubt that religions in their different forms have served as a source of hope and have also functioned as a reservoir that sustains the human spirit. Digitisation has also functioned as a space and a reservoir where hope and faith are sustained. In the following section, a brief discussion on the role of religious digitisation follows.

\title{
Digital communication in the period of COVID19-pandemic
}

On 11 March 2020, the World Health Organization announced the COVID-19 as a virus pandemic after a notable spread in various countries worldwide. In Dutra and Rocha's (2021:99) understanding, the contagious nature of the virus and reported deaths forced governments worldwide to introduce lockdown regulations; social distancing, wearing of masks, regular washing of hands, and disinfection. On the dark side of things, social distancing rules negatively impacted the operations of religious houses across the world, and more so 
for Muslims who are strong religious people (Wibisono et al., 2021:28). In addition, there are strict limitations in terms of the number of attendees allowed in one venue. At times, during periods of accelerated spread, churches are not allowed to operate at all.

Many religious houses and pastors used online platforms such as Facebook, Twitter, Microsoft Teams, Zoom, and Skype to provide social support to patients of the COVID19-pandemic in their quarantine spaces, including hospitals (Vorvornator, 2021:14). This had its advantages and disadvantages depending on the demographics of various populations. For marginalised communities, access was a train-smash given data expenses and load shedding, particularly for older people in African countries such as South Africa. On the contrary, civilised and young people in communities benefited from services offered through these platforms.

Stemming from the above background, the researchers conducted an empirical study to explore nurses' experiences that contracted COVID-19 in rural-based hospitals. The focus was to highlight the intersectionality of religion, race, and gender during the COVID-19 pandemic.

\section{Methods}

This section highlights the study design, setting, study population, data collection, and data analysis.

\section{Study design}

The researchers followed an interpretative phenomenological analysis (IPA) design. The design was considered most suitable to gain an in-depth understanding of the nurses from a rural-based hospital who contracted COVID-19 and the intersectionality of religion, race, and gender on the COVID-19 pandemic. The IPA design assisted the researchers in making sense of how the participants view their experiences which is the double hermeneutic (Smith \& Osborn, 2015:16). The design also has an idiographic element that focuses on how participants view and interpret their experiences (Smith 2017:17). As COVID-19 has brought a broad influence on people's religiosity, influenced by issues of race and gender, the IPA was considered the most relevant design.

\section{Study setting}

The study was conducted in a South African rural-based public hospital in the Vhembe district of Limpopo province. The hospital caters for African patients who are from impoverished rural communities in the former rural Venda homeland. Due to 'separate development', which occurred during the apartheid era, the hospital is under-resourced. There are no medical specialists or specialist units. All the people working at the hospital are Africans, and most of them are from the Vhembe district and are Tshivenda speakers.

\section{Study population and sampling}

The study population comprised of nurses working at the study site who had contracted COVID-19. The eligible participants were nurses who had shown the symptoms of COVID-19 and were quarantined for at least ten days, also those who are a member of a religious community and of the Vhavenda ethnic group, staying in Vhembe District. These eligibility criteria were considered necessary as the researchers assume that they know the Vhavenda cultural practices. 
Before approaching the participants, the researchers had secured ethics clearance from the University of South Africa, College of Human Sciences Research ethics committee (ethics reference number 90187598_CREC_CHS_2021). The researchers also obtained permission to conduct research from Limpopo Department of Health (LP_2020_02_004) and the hospital, which is the study site (Ref S4/2/1/1/3).

Due to the sensitivity of the topics and issues of confidentiality, the researchers reached potential participants through the operational managers of the hospital. After understanding the purpose of the study and ethical implications, the operational managers recruited the nurses who met the inclusion criteria. The nurses were provided with the researchers' contact details to enable those willing to participate to contact the researchers by sending a "please call me" message, which is free of charge. One of the researchers contacted the participants and provided all the relevant study requirements, including that the research participation was voluntary, confidentiality was going to be adhered to, that participants could use pseudonyms, audio-recording of interviews, and respect was going to be upheld in order to obtain verbal informed consent. A total of 11 nurses consented to participate, which was an adequate sample for the IPA study, according to Smith et al. (2009:33).

\section{Data collection}

Data were collected in April 2021 through telephonic conversations in adherence to COVID19 regulation lockdown level 4, which prohibited inter-provincial traveling and limited movement. The interviews were guided by an interview guide composed of core questions and probes. Each interview was introduced through the following wording: Kindly share with me your experience subsequent to the diagnosis of COVID-19? In addition, the following are some of the prompts used: What was the source of your healing?; How did your religion help you?; How did your religion influence your choice of treatment?; Why did you not get hospitalised?; and how does that make you feel? If it was not due to your religious belief, what would you have done differently? The researchers audio recorded the interviews following participant's informed consent. During the interviews, the researchers jotted down the nonverbal cues such as tone of voice, silence, sighing, and other audible sound, and probed further based on that.

\section{Data Analysis}

The researchers transcribed the audio recordings verbatim and independently analysed the data following the steps highlighted in Pietkiewicz and Smith (2014:8). The steps include: listening to the audio recordings, reading transcripts repeatedly to gain an in-depth understanding, interpreting the participants and also writing reflexive notes on how the participants presented their experiences, identifying emergent themes based on the phrases from the transcripts, clustering themes into superordinate themes and dropping unrelated themes.

\section{Results}

The results section is divided into biographical data and the experiences of nurses who suffered from COVID-19 infections, which depicts the intersectionality of religion, race, and gender during the COVID-19 pandemic.

\section{Biographical data}

The participants were nurses aged between 31 and 60 years. They were from different ranks within the nursing structure, including their experience levels ranging between 6 and 40 years. 
Two of the participants were from mainline churches, two from African Independent Churches, and the majority (seven) were from charismatic churches. The summary of the biographical data is displayed in Table 1 using pseudonyms to ensure confidentiality.

Table 1: Participants biological data

\begin{tabular}{|l|l|l|l|l|l|l|}
\hline Name & $\begin{array}{l}\text { Age } \\
\text { range }\end{array}$ & Sex & $\begin{array}{l}\text { Occupational } \\
\text { Rank }\end{array}$ & $\begin{array}{l}\text { Number } \\
\text { of years } \\
\text { in } \\
\text { Nursing } \\
\text { (range) }\end{array}$ & $\begin{array}{l}\text { Marital } \\
\text { Status }\end{array}$ & Religious Affiliation \\
\hline Masindi & $41-50$ & $\mathrm{~F}$ & $\begin{array}{l}\text { Enrolled } \\
\text { Nursing } \\
\text { Assistant }\end{array}$ & $\begin{array}{l}\text { Between } \\
6-10\end{array}$ & Married & Mainline churches \\
\hline Phophi & $51-60$ & $\mathrm{~F}$ & $\begin{array}{l}\text { Registered } \\
\text { Nurse }\end{array}$ & $35-40$ & Married & Charismatic church \\
\hline Mashudu & $51-60$ & $\mathrm{~F}$ & $\begin{array}{l}\text { Registered } \\
\text { Nurse }\end{array}$ & $35-40$ & Married & Charismatic Church \\
\hline Mukondi & $31-40$ & $\mathrm{~F}$ & $\begin{array}{l}\text { Registered } \\
\text { Nurse }\end{array}$ & $6-10$ & Married & Charismatic Church \\
\hline Mafa & $41-50$ & $\mathrm{M}$ & $\begin{array}{l}\text { Enrolled } \\
\text { Nursing } \\
\text { Assistant }\end{array}$ & $11-15$ & Married & Mainline Churches \\
\hline Mutendi & $51-60$ & $\mathrm{M}$ & $\begin{array}{l}\text { Registered } \\
\text { Nurse }\end{array}$ & $35-40$ & Married & Charismatic \\
Church
\end{tabular}

\section{The positive impact of religion on the management of pandemics}

In normal circumstances, any person's religious or spiritual aspect is considered to be a crucial social tie. For this reason, they cannot be overlooked in policymaking or decisions concerning the health of individuals during pandemics or generally. Historically and to date, religion has and always plays a critical role in health promotion. This is not the case in the current modernised society. COVID19-pandemic made things more difficult for the religious community, with the government introducing social distancing, wearing a mask, and hygiene measures to minimise the spread. Until today, the health care sector can only intervene by reducing the symptoms of the virus. There is no cure for the COVID19-pandemic, and the vaccination programme causes suspicions (Barmania \& Reiss, 2020:1757; Fardin, 2020:16).

It can be argued that the pandemic exposed the extent of poverty in South Africa (United Nations Development Programme in South Africa 2020:38). It also uncovered the intersections between poverty, race, and gender. As the poor became poorer, it affected mostly women and children. Thus, necessitating a question what is the colour of poverty? Leading to an uncomfortable answer: the colour of poverty is Black. 
The Bible is a liberating text, and the poor have read the text from various perspectives, namely, political, economic, gender-wise, and liberative. The text read through these hermeneutical lenses has created an opportunity for the marginalised to 'speak truth to power', attempting to make a difference in the people's lives and in diverse situations.

Ogolla (2020:16) has argued that religions worldwide have created a space for the state to provide health care services. He further alluded that in the age of a catastrophe, the churches are often charity paragons. For example, during COVID-19, in April 2020, the International Christian Rescue Organization, Samaritan's purse, built an emergency hospital in Italy and in New York.

In addition, Kaman Churches in Osaka and Tokyo have decided to utilise their counselors' expertise to know the suffering, trauma, stress, anxiety, and despair that people suffer from with the Covid-19 pandemic and generally provide free consultation services (Vorvornator \& Mdiniso, 2020:454). The church also provided accommodation to residents of Tokyo and Osaka who lost their housing due to emergency responses. The place was named "Internet Cafe Refugee" at the Osaka Catholic Church (Vorvornator \& Mdiniso, 2020:455; Cavaliere, 2020:454). Covid-19 has been recorded to affect the poorest and most vulnerable people. Shines, temples, churches, and schools have switched to settlements to accommodate society's poor and vulnerable people. Churches, temples and shrines do not discriminate in connection with providing help to those in need. Believers and non-believers alike are kept under their shelters (Cavaliere, 2021:31; Cavaliere, 2020:455). Covid 19 has made most of the nurses who tested positive become very close to God. Though they could not go to church due to quarantine restrictions, they considered the issues of spirituality as the main source of their strength. Their dependence on God was evidenced by either praying individually, receiving prayers from their pastors, or peer prayers.

\section{Praying individually}

Covid-19 had made several people trust in God more for healing. As a result, they prayed more than they used to do before COVID-19.

I was praying continuously. Saying that I trust in you, God and that you know me. I know that my life is just through the grace of God. I constantly sing that: 'Our trust is in You God,' and 'I will never forget what Jesus Has done for me.' Na Luke 1: 37 says that there is nothing impossible with God. That verse is my everything. I was continuously trusting in GOD. Finally, I am grateful to GOD. It was God's grace. (Mashudu)

One day, when I was praying, I could not continue praying aloud because my voice was cutting. I continue to pray in silence. Every time I felt like I was gasping for air, I would just say, God, do not let me die now. I am now very grateful to GOD because I know I would have died if it was not Him. (Masindi)

I think that the prayers have worked because I was continuously praying. My prayers and those for people praying for me have helped. I think it is a miracle for me to be alive as I could not breathe without oxygen from 7 January to 1 of 2021. But that speedy recovery and me being discharged from the hospital, I believe it was God's intervention. (Mafa)

I was praying continuously, saying that I trust in you, God and that you know me. I know that my life is just through the grace of God. (Mukondi) 


\section{Prayers from Pastors}

Participants mentioned that what made them recover from COVID-19 was the continuous online prayers from their pastors:

Spiritually, I was praying day and night. My husband wanted to take me to the hospital, but I refused to go. I requested the phone number of the pastor so that he could pray for me. After the pastor prayed for me, he kept on phoning me every day until I fully recovered. (Mashudu

My sister was also anxious and called her pastor and started to pray for me before going to the hospital. (Mavhungu)

\section{Prayers with other nurses who tested positive to COVID-19}

Peer prayer was one of the sources of spiritual support. This was in the form of waking each other up to pray or send Bible messages during the night.

This situation has encouraged me to trust in God. I have seen God. I have seen his grace. We had a chain of prayer where people would call each other and continue to pray, especially during the night. (Phophi)

\section{Encouraged to pray by nurses in the ward}

The faith in God was not only for nurses infected with COVID-19 but also for the nurses caring for infected patients as they felt that the patient who died was because of not trusting God or losing hope.

When I went to the ward, nurses said I should have more faith in GOD. They said people who have died are the ones who lose hope. I was requested to be on bed rest for 24hours without even going to the toilet because if I go out of bed, I may collapse and die. I kept on praying. I kept on saying I was not going to die. God will heal me. (Phophi)

\section{Prayers from other nurses}

Participants were further receiving prayers from nurses and even the hospital manager.

The nurses in the ward and the matron were continuously phoning, giving me support, and praying for me. The matron would come and pray for me every day. (Mafa)

\section{The use of indigenous medicines as therapeutic against COVID-19 infections}

During COVID-19, people reported on the use of different types of medicine. The focus was not only on Western medicine, but people were mixing both western and traditional African medicine.

Though we were emphasising different drugs in the hospital, most people at home were steaming using traditional herbs, such as mibomo, mibirbiri, vics, eating garlic and honey, lemons, and tshiumbeumbe. The majority of people used those traditional African medicines. So, most people who recovered mentioned that they recovered due to $u$ aravhela (steam inhalation). Even when we were traveling, we saw people next on the road, selling tshiumbeumbe and Mibomo. (I think some families get economic support through selling honey, tshiumbeumbe, mibomo, and some eucalyptus oil (which smell like mubomo), so they were making some money. (Khangala) 
It is like during COVID-19, some of the trusted western medicines were not so effective.

\begin{abstract}
I think the medicines were also a problem as I was reacting to Asprin and prednisone. The cough syrups were also not helping me at all, but just making me more sick. The doctor also makes sure that I should stop using all those treatments. I was using only atibiotics and vitamins. (Mafa)
\end{abstract}

However, while almost all the nurses interviewed have used traditional African medicine, one of the participants did not use any of the traditional African medicines. She considers traditional African medicines as part of being a heathen as they are supposed to be used by by the witchdoctors.

\begin{abstract}
I was given traditional African medicine like tshiumbeumbe, but I did not use it. What I did, was to steam myself with water and drinking hot water. I did not believe in traditional African medicine. This was because of my religious belief. I have never used traditional African medicine. I grew using prayer and believing in prayer. All those medicines are considered things of heathen who believes in witch doctors and witchcraft. (Mutendi)
\end{abstract}

\title{
Religious gullibility against vaccination: COVID-19.
}

Most of the nurses who suffered from COVID-19 were not yet vaccinated. The reasons for non-vaccination were based on the belief that COVID-19 is one of the diseases that signifies that the world is about to end.

I did not believe in the vaccination. We have been taught that this COVID-19 is one of the diseases mentioned that there will be incurable diseases that will kill a lot of people towards the end of the world. The first one was HIV. And now is COVID-19. These diseases are from the devil. So, vaccinations are just a waste of time as they will not help us. (Muofhe).

I will never be vaccinated. They may rather kill me or expel me from work. You know, this injection is part of the sign of antichrist. So, they will be giving us the vaccine, but it is that triple six number. Meaning that if you are vaccinated now, you are captured by the devil. Soon they will say that if one is not vaccinated, they will not be allowed to buy anything from any shop. I rather die instead of subjecting myself to the devil. At least I know that God will always keep me safe. You know, I am already 60 , and if I die, it will be time. (Mavhungu)

The argument raised above from one of the participants illustrates the epistemological tensions between Western and African epistemologies. This is expressed in their resistance to administer traditional African medicine in addition to their use of Western medicine. At the same time, it can be observed that those that were administering both the traditional African and western medicines experienced some form of labelling/ and or categorisation. In that, their use of traditional African medicine located them as being against the church's teachings and thus, they were viewed as engaging in heathenism. This indicates the multifacetedness in the manner in which one can observe the divergence of the two worlds in terms of the values, norms and standards. The divergence is further heightened by discrimination and stigmatisation of those who opt to either administer western or traditional African medicines or use both. We would contend that such 'Othering' takes place across gender lines. We further maintain that such 'Othering' finds its legacy from the epistemic violence that colonisation and apartheid performed on black bodies. At the same time, those that are 'Othered' as using heathenistic practices are engaging in what can be regarded as epistemic disobedience. Above all, their application of epistemic disobedience has to be located from the social and 
epistemic locations. Succinctly put, their social location is that of being underprivileged, poverty and class. While their epistemic location is the indigenous knowledge system that has sustained them.

Therefore, it can be argued that the heightened epistemological tensions that COVID-19 brought on has led to the attempt to level the epistemological fields as shown in the acknowledgment of indigenous health care and its medicines. This is also shown well as the attempt by western colonial Christianity to use the Bible as an imperial tool to erode in order to bring about cultural revolution. Mbembe (2001: 230) refers to the notion of a cultural revolution in the following manner. He states,

\begin{abstract}
Therefore, from a theological point of view, conversion is a way of exercising violence against the state of mortality; the convert is supposed to move from death to life-or, in any event, to the promise of life. This tends to suggest that conversion always involves an act of destruction and violence against an earlier state of affairs and an accustomed state for which one seeks to substitute something different. This act of violence and destruction is always carried out in the name of specific materiality, one that claims to oppose a system of truth to an order of error and falsehood.
\end{abstract}

\title{
The notion of Blackness, poverty in the era of COVID-19
}

An analysis of the role and impact of religion in the era of COVID-19 must be done from the perspective of the damnés in Fanonian terms (Fanon, 1963). This is because society is hierarchised not only in terms of economic privileges but also in terms of gender, race, political, social, and religious stratifications. This is observable in the preceding sections that for a proper analysis to be done, one needs to locate these intersectionalities within the social and epistemic location of the black body. It is for this reason that in relation to the COVID-19 pandemic, not only should we approach our analysis of it from the perspective of compartmentalising the issues surrounding the effects of COVID-19, we ought to do that from the geo-politic and theo-politics of knowledge informed by the socio-epistemic locations of the damnés (the damned) or what Fanon refers to as the zone of nonbeing (Fanon, 1963). Pinn's (2010:63) analytical lens becomes paramount in critiquing and evaluating the impact of religion from the perspective of the colonised (bodily and epistemologically). He offers an alternative interpretation of the Black body contrarily within the context of Black theology. It is this analytical perspective that we would be applying in analysing the black experience in the era of COVID-19 and the intersectionalities of religion, race, gender and class.

Pinn's analytical lens of the Black body goes against the grain of the traditional Black and Womanist Theology in terms of their Christian-centred focus (Pinn, 2010:75). For Pinn the Black bodies are at the centre, rather than placing God or Christ at the centre of his theology. Such an approach is crucial because not only does it seek to magnify the struggles and resilience of black bodies, it problematizes the very notion of a racial God that western Christianity has taught. He states, "Black theological thought related to issues of liberation and life meaning, when framed in terms of the body, tend toward the body only as abstraction, as symbol with little attention to the lived body"). Pinn (2010:75) further complexifies the approach of centring the divine by crafting a Black theological reflection that embraces the Black body at its centre. Pinn's approach locates the black body and how it is viewed in what Grosfoguel refers to as "animperial/capitalist/colonial world-system. Race constitutes the transversal dividing line that cuts across multiple power relations such as class, sexual and gender at a global scale" (2016: 11).

He argues that it is in understanding how racism and White supremacy are experienced physically by the material body, and ignoring this reality is to ignore the materiality of liberation. The argument by Pinn has been argued by scholars such as Davis (1983) and Crenshaw 
(1991) who have conceptualised the "intersectionality" of race, class, sexuality and gender hierarchies, as occurring in both zones of the world in Fanonian terms. Pinn's conceptualisation of the body is one that deliberates on both the biochemical realities of the body and the ways in which it is formed and understood by social discourse and power relationships. His analysis of social discourse and power relationships is informed by Foucauldian analysis of power and body. Succinctly put, it is important for Pinn, that we identify the body as both parts, namely the discursive and the material, simply because the two parts are inseparable. The work of Butchart in the context of South Africa links with Pinn's analytical lens. Butchart, unlike Pinn does his analysis from the psychological perspective in that he highlights how power in Foucauldian terms was used by Europeans to construct black bodies in what he refers to as the 'spectacle of healing'. He states (1998: 81),

The spectacle of sovereignty addressed the onlookers in whose beliefs and deeds were reproduced the forces of darkness that had to be made to bow to çivilization'. But running alongside, almost incidental to the drama that attracted the Africans'attention, coursed the whispering currents of disciplinary power: through the doctor, through the catheter and the stethoscope, and through the body of the patient whose blood filled the cupping glass.

To critically engage with the effects of religion as strata within the colonial matrix power and how it intersects with the current conditions that Black bodies are understood and linked with the ways that racist and White supremacist social power structures have on the physical impact on the Black body, as well as how one can work to address the roots of that physical impact, particularly in the current era. He argues that "physicality is necessary in order to understand and work through oppressive circumstances and address the pain and suffering promoted by those circumstances. Power relations are not simply thought (notions) but are performed through the placement of real, fleshly bodies in time and space" (Pinn, 2010:82). Pinn's analysis becomes essential in analysing the suffering and pain in the context of COVID19. This is evident in his rejection of the usefulness of theodicy as "theological throat-clearing", giving inclination instead to an "embodied response" that advances not only the individual's experience but also the larger, structural, systemic issues that lead to the harm of the body.

The centering of the Black body is an important element in order to properly analyse the role and effect of religion in the era of the COVID-19 pandemic. In other words, such an analysis from the perspective of Blackness will not necessitate the centering of the black struggle and resilience but will also function as a space for healing. This is because, over the centuries, Black bodies have experienced a multifaceted form of ailments, marginalisations, struggles and resilience as Pinn (2010) and Butchart (1998) have convincingly argued in their works. These struggles of poverty, unemployment, dislocation, disenfranchisment $t$ are exacerbated by the intersectionalities of race, gender, and class that the socio-economic conditions have deepened as a result of the COVID-19 pandemic. Furthermore, as demonstrated in the preceding section, those in the rural areas continue to be affected by these cartographies of struggle that have impacted their geo-spatial location. Therefore, it can be argued that these historical injustices and deprivation, as highlighted earlier, have not only been a matter of socialisation but are multifaceted in that they take racial, political, and economic systems and gendered, environmental, sexual, psychological, cultural, spiritual and religious methods as argued by Soja (2010:1). In other words, these injustices are to be analysed within what Maldonado-Torres refers to as 'coloniality of power' (2007). Maldonado-Torres argues that "the idea was that colonial relations of power left profound marked not only in the areas of authority, sexuality, knowledge, and the economy but on the general understanding of being as well" (2007:242). Based on the argument by Maldonado-Torres, it can be argued that the existing conditions have been deepened by COVID-19 pandemic as such impacted on the already unstable geo-spatial location of Black bodies. 
This ongoing state of socio-geo-political injustices in relation to the colonised Black communities, as argued in the preceding sections, are in part owing to, as Soja suggests, the fact that historical "[in]justice has consequential geography" (2010:1). He continues to argue that the consequences of geographical injustice incorporate the geographical mappings of both the physical and the political boundaries. This includes the geography of ideas, images, and normative structures. The observation by Soja resonates with the argument by Maldonado-Torres in that for him, the consequences of geographical injustices he categorises it as coloniality of being. He states (2007: 242),

\begin{abstract}
While the coloniality of power referred to the interrelation among modern forms of exploitation and domination (power), and the coloniality of knowledge had to do with impact of colonization on the different areas of knowledge production, coloniality of being would make primary reference to the lived experience of colonization and its impact on language.
\end{abstract}

It can be argued that the geographical injustices find their meaning in the coloniality of power, language, and knowledge which is a view held by both Soja (2010:2) and Pinn (2010:75) in terms of locating the Black experience within the larger, structural, systemic issues. In other words, the coloniality of power and that of being. The work of Fanon (1968), in this instance, provides us with an analytical lens for depicting the master/slave dialectic. It further contributes to a more general rethinking/reconceptualisation similar to that of Pinn and Soja on the notion of ontology in the context of coloniality of being, particularly at the time of COVID-19. Arguably, the pandemic intensified the persisting conditions of poverty, exclusion, and also limitation to health care that find their genesis in colonisation and apartheid, and have worsened since post-liberation.

These geographical injustices further illustrate the uncomfortable reality that the mere variations in the phenotypes of Black bodies that occupy political spaces of power within the physical boundaries of a nation state cannot, in one act, eradicate the enshrined history of inequality and injustice performed on Black bodies, or the land and cultures where they live within the colonial matrix of power in decolonial terms. Such conditions has been argued, are to be understood and critiqued from the perspective of coloniality based on the enduring systems of power that occurred succeeding from colonialism. The concept of the colonial matrix of power is borrowed from Mignolo's (2011:449) articulation of Anibal Quijano. In terms of Quijano's definition of the colonial matrix of power. We follow Mignolo's understanding of the 'modern/colonial world' and 'colonial matrix of power' as part of the same historical complex, but not as substitutes. As Mignolo (2011:450) rightly observes, "the colonial matrix of power' is the specification of what the term 'colonial world' means both in its logical structure and in its historical transformation".

Succinctly put, Black communities continue to bear the marks of the "dominant geographies" (Soja, 2006:26) of western, white, colonial narratives and histories that have resulted in a legacy of violence, marginalisation and attempts at erasure of Black political, cultural, religious and intellectual (Indigenous Knowledge System) practices and ideas. In other words, it is in Black communities that the patterns of power endure. Resulting in what Biko refers to as selfhate or a flight from the Black self. The legacy of this violence (both physical and symbolic) and its extensive effects are indelibly engraved into the spiritualities, epistemologies, settings and existential spaces of the Black communities.

Nevertheless, the enduring violence of the colonial matrix of power expressed in the geographical oppression, injustice, epistemic violence, spiritual epistemicide, geo-politics of knowledge, theo-politics of knowledge, demonisation of diviner-healers and delegitimisation of traditional African medicines by western scientific bodies operating within colonial matrix power, has led to Black communities to engage in what McKittrick (2006:23) defines as "Cartographies of struggle" in which they continue to claim and reclaim their social locations and epistemic locations in the forms of indigenous knowledge systems and the constant 
innovation to break from the grip of the colonial matrix of power that is sustained by coloniality. While at the same time they are cognisant of the realities that the colonial matrix of power is fluid and transmogrifies itself through epistemic privilege and erosion of other knowledge systems. The impact of COVID-19 on Black communities has not prevented Black bodies from engaging in protest, and perform agency against the systemic racism, inequalities, and access to health care. In our analysis of these cartographies of struggle as defined by Soja (2010:3), becomes handy in the following manner: "situated and contextualized in three overlapping and interactive levels of geographical resolution" that include (1) the "external creation of unjust geographies through boundary making and the political organization of space"; (2) the local (including interpersonal) "distribution of inequalities" and "discriminatory decision making by individuals, firms, and institutions"; and (3) middle scale forms of regional or mesogeographical manipulation connected with "uneven development" and "the globalization of injustice" (Soja, 2010:9). Since COVID-19 not only has it affected every nation across the globe. It has adversely affected Black communities. In the context of South Africa, Black bodies occupy mostly disenfranchised, dislocated, displaced, and impoverished space. These cartographies of struggles are to be located within the colonial matrix of power.

The pandemic has not only intensified the geographical injustices within Black communities, but it has also heightened the resilience of these communities, resulting in the exercise of geographical agency in ways that subvert the dominant geographies of the colonial past through the use of indigenous knowledge systems. In other words, the geographical agency Black communities have, further opened up the epistemic privilege that continues to reside within the colonial missionary/western health system through their use of traditional African medicines. Such moves have led to the call for complete recognition of complementary medicines such as indigenous herbs/plants. Wild (2020: n.p.) points out disagreements over how traditional remedies ought to be scrutinized and analyzed, noting that scrutiny remains tied to Western methodologies and protocols. She states:

\begin{abstract}
Scientists, public officials, and traditional healers all seem to agree that traditional African medicines must be shown to be safe and effective. The sticking point is how this should happen. And despite a newfound willingness to engage with traditional African medicines, Sahpra's evaluation unit will face practical difficulties in evaluating African traditional African medicines including the lack of written records.
\end{abstract}

Finally, Black cartographies of struggle do not only pertain to the socio-geo politics of knowledge, but also the epistemic locations aimed at reclaiming Black conceptual spaces comprising of social, spiritual, epistemic, political, and imaginative spaces with the purpose of autheticating Black bodies, languages, religious and discursive practices within those spaces. As Wild has argued, these cartographies of struggle will have philosophical and theoretical implications for broader notions of black enablement, identity, and community post the pandemic. Thus, simplifying the resilience that resides in these Black communities.

Based on the above, the idea of religion as a space of reimagining and as cartographies of struggle finds resonance in the way black bodies recreated such spaces. Spaces of hope, validation, empowerment, identity and community. Thus, the centering of the Black body as illustrated earlier does not only empower the disenfranchised, even in the era of COVID- 19.

\title{
Conclusion
}

In this paper, we have attempted to map out the intersectionalities of region, race, gender and class in the era of COVID 19 in the context of South Africa. We argued that such a context is imperative in the analysis of religion and its impact on the notion of gender, race and class in the era of COVID-19. We further maintained that one of the challenges is the fundamentalist approach in the interpretation of biblical texts such as the book of Revelation. Highlighting the politics of interpretation in the use of the biblical imagery like 666, and the antichrist. At the 
same time we argued that western colonial Christianity through its missionary activities sought to perform a technology of erosion by categorising the indigenous spiritualities as being heathen thus leading to spiritual epistemicide and epistic violence. Such an observation is evident in the people interviewed, the healthcare providers, who were expected to rely on Western medicine by virtue of their profession, negating the indigenous knowledge systems. This we argued magnified the divergence between the two epistemologies based on the notion of epistemic priveledge that western epistemology has constructed. An interesting observation was that though they epistemologically located themselves within the western paradigm, they did not rely exclusively on a western health system. Instead they placed their belief in the western colonial Christian God, based on the notion of 'praying without ceasing'.

Almost all of the interviewees make use of traditional African medicines such as steam inhalation using mubibiri leaves, tshiumbeumbe, lemon tree leaves, eucalyptus tree leaves, Linana or heated stones. This is an indication that Black communities are not only performing epistemic violence but they are reimagining and reclaiming their heritage, thus performing what decolonial scholars refer to as 'delinking'. The local communities in South Africa continue to depend and recognize the value of an indigenous knowledge system in relation to traditional African medicines and they continue to use and administer these medicinal plants for basic healthcare; and the use of traditional African medicines is still an integral part of their sociocultural life.

We further argued that coloiniality of being and of knowledge, is one of the technologies of power that western colonial Christianity has performed on Black bodies. This is seen in the interviews we held were only one participant argued that her religious beliefs particularly coming from a religious family, means she cannot use traditional African medicines including herbs as those medicines are for heathens. COVID-19 has magnified the gegraphies of injustice that Black communities are experiencing. It has further led to a conversation of pluversality vs uni-versality of knowledge, leading to Black communities utilising their indigenous resevoirs of knowledge. At the same time, it is observable that such a move is not enough as the colonial gaze is performed within the coloniality of power, being and knowledge. COVID19 has only created the space for such a move, the journey of decolonisation has just only begun.

\section{References}

Barmania, S. \& Reiss, M. (2020). Health promotion perspectives on the COVID19 pandemic: the importance of religion. Global Health Promotion, 28(1), 1757- 9759. [Available online at https://doi.org/10.1177/1757975920972992].

Belvins, J. (2020). COVID-19, Religion and the Importance of Effective Leadership. [Available online at https://blogs.Ise.ac.uk/religionglobalsociety/2020/04/Covid-19-religion-and-theimportance-of-effective-leadership/]

Biko, S. (1978). I write what I like: selected writings. Chicago: The University of Chicago Press.

Butchart, A. (1998). The Anatomy of Power: European Construction of the African Body. Pretoria: Unisa Press.

Cavaliere, K., Levine, C., Wander, P., Sejpal, D.V. \& Trindade, A. J. (2020). Management of upper GI bleeding in patients with COVID-19 pneumonia. Gastrointestinal Endoscopy, 92(2), 454.

Cavaliere, P. (2021). Religious institutions in Japan responding to COVID-19-induced risk and uncertainty: some preliminary considerations. Journal of Religion in Japan, 10(1), 31-63. 
Crenshaw, K., 1991. Mapping the margins: Intersectionality, identity politics, and violence against women of color. Stanford Law Review, 43(6), 1241-1279.

Davis, A. 1983. Women, Race and Class. New York: Vintage

Dutra, C.D. \& Rocha, H.S. (2021). Religious support as a contribution to face the effects of social isolation in mental health during the pandemic of COVID19. Journal of Religion and Health, 60, 99- 111

Ede, V.I. \& Zuokekalu, D. (2021). Coping with COVID19 pandemic in Africa: the religious coping option. Journal of African Studies and Sustainable Development, 4(1), 2630- 7073. [Available online at https://doi.org/10.13140/RG.2.2.12616.55046]

Fanon, F. (1963). Wretched of the earth. Translated by Richard Philcox, New York: Grove Press.

Fanon, F. (1968) Black Skin, White Masks. TranS. Charles Lam Markmann. New York: Grove Press.

Fardin, M.A. (2020). COVID19 endemic and spirituality: a review of the benefits of religion in times of crisis. Jundishapur journal of Chronic Disease Care, 9(2). [Available online at https://dx.doi.org/10.5812/jjcdc.104260].

Foucault, M. (1989). The Order of Things: An archaeology of the human sciences. New York: Routledge.

Foucault, M. (1977). Discipline and punish. A. Sheridan, Tr., Paris, FR, Gallimard. London: Penguin.

Foucault, M. (1978). The History of Sexuality, trans. by Robert Hurley, New York, NY: Pantheon Books.

Foucault, M. (1983). "The Subject and Power, "Beyond Structuralism and Hermeneutics (eds., by H. Dreyfus and P. Rabinow, The University of Chicago Press.

Grobler, R. (2020). God must destroy 'mark of the beast' Covid-19 vaccines - Mogoeng defends his controversial prayer. News 24. [Available online at https://www.news24.com/news24/SouthAfrica/News/god-must-destroy-mark-of-the-beastvaccines-mogoeng-defends-his-controversial-prayer-20201211]

Grosfoguel, R. (2016). What is Racism?. Journal of World- Systems Research, 22(1), 9-15.

lase, A. (2017). The interpretative phenomenological analysis (IPA): A guide to a good qualitative research approach. International Journal of Education and Literacy Studies, 30, 5(2), 9-19.

Isiko, A.P. (2020). Religious construction of disease: an exploratory appraisal of religious responses to COVID19 pandemic in Uganda. Academic Journals, 12(13), 77-96 . [Available online at https://doi.org/10.5897/JASD2020.0573].

Knight, D., Dudenkov, D.V. \& Cheshire, W. P. (2021). Religion in the US during the time of a Pandemic: A Medical Perspective. Journal of Religion and Health, 1-16. DOI:10.1007/s10943021-01366-8 
Lazarus, R.S. \& Folkman, S. (1984). Stress, appraisal, and coping. New York: Springer publishing company,.

Maldonado-Torres, N. On the Coloniality of Being. Cultural Studies, 21(2), 240-270.

Marshall, C. (2005). What language shall I borrow? The bilingual dilemma of public theology. Stimulus, 13(3), 12-18.

McKittrick, K. (2006) Demonic Grounds: Black Women and the Cartographies of Struggle, Minneapolis: University of Minnesota Press.

Mignolo, W.D. (2011). 'Delinking': The rhetoric of modernity, the logic of coloniality and the grammar of de-coloniality. Cultural Studies, 21(2), 449-514.

Mothoagae, I.D. (2018). The reordering of the Batswana Cosmology in the 1840 EnglishSetswana New Testament. HTS: Theological Studies, 74(1), 1-12.

Ogolla, C. (2020). Does Religion Matter During a Pandemic? [Available online at https://berkleycenter.georgetown.edu/responses/does-religion-matter-during-a-pandemic].

Pietkiewicz, I. \& Smith, J.A. (2014). A practical guide to using interpretative phenomenological analysis in qualitative research psychology. Psychological Journal, 20(1), 7-14.

Pinn, A.B. (2010) Embodiment and the New Shape of Black Theological Thought (Religion, Race, and Ethnicity), New York: New York University Press.

Polit, D.F. \& Beck, C.T. (2014). Essentials of nursing research. Appraising evidence for Nursing. Lippincott Williams \& Wilkins, Philadelphia

Rigoli, F. (2020). The link between coronavirus, anxiety and religious beliefs in the United States and Kingdom. [Available online at https://doi.org/10.31234/osf.io/wykeq].

Smith, B.W., Pargament, K.I., Brant, C. \& Oliver, J.M. (2000). Noah revisited: Religious coping by church members and the impact of the 1993 Midwest flood. Journal of Community Psychology, 28(2), 169-186.

Smith, J. A. (2017). Interpretative phenomenological analysis: Getting at lived experience. The Journal of Positive Psychology, 12(3), 303-304.

Smith, J.A., Flowers, P. \& Larkin, M. (2009). Interpretative phenomenological analysis: Theory, Method and Research. Los Angeles, CA: SAGE;

Smith, J.A. \& Osborn, M. (2015). Interpretive phenomenological analysis. In. Smith, JA. Qualitative psychology: A practical guide to research methods.

Soja, E.W. (2010) Seeking Spatial Justice, Globalization and Community Series Minneapolis: University of Minnesota Press.

United Nations Development Programme South Africa. (2010). COVID-19 in South Africa. Socio-economic impact assessment. Pretoria: United Nations Development Programme, Pretoria. 
Vorvornator, L.K. (2021). The COVID19 pandemic and religious activities: a case study of Esikhaleni settlement. Pharos Journal of Theology, 102(2). [Available online at https://doi.org/10.46222/pharosjot.102.2131.

Vorvornator, L.K. \& Mdiniso, J. (2021). The Covid-19 Pandemic and Religious Activities: A Case Study of Esikhaleni Settlement. Pharos Journal of Theology, 102(2).

West, G.O. (2016) The Stolen Bible: From Tool of Imperialism to African Icon. Pietermaritzburg: Cluster Publications.

Wibisono, M.Y., Truna, D.S. \& Rahman, M.T. (2021). Turning religion from cause to reducer of panic during the COVID19 pandemic. Theological Studies, 77(4).

Wild, S. (2020). Traditional and mainstream medicine have long been at odds. But Covid19 may be driving a new, evidence-based reckoning, Undark: [Available online at https://undark.org/2020/12/30/covid-19-south-africa-traditional-medicine/] 